\title{
SOCIALINIO SOLIDARUMO MOTYVAI ARCHITEKTO VYTAUTO LANDSBERGIO-ŽEMKALNIO KŪRYBOJE
}

\author{
Vytautas Petrušonis \\ Architektūros pagrindų ir teorijos katedra, Vilniaus Gedimino technikos universitetas, \\ Pylimo g. 26/Traku 1, 01332 Vilnius, Lietuva \\ El.paštasv.petrusonis@tkti.lt
}

Iteikta 20100623

\begin{abstract}
Santrauka. Šiuolaikinëje visuomenëje didèja atskirtis, socialinių grupių nesusikalbėjimas, užsisklendimas, kuriant grupinius idealus, siekiant nereikšmingų tikslų. Greta kitų dalykų, tai susiję su socialinio solidarumo kaita, kuri veikiama tokių šiuolaikinès civilizacijos reiškinių kaip individualizacija, diversifikacija, globalizacijos procesas, segmentacija. Šiuolaikinès kartos architektų, kartu su užsakovais esančių savojo laikotarpio atstovais, darbai ypač dažnai atspindi siekị dominuoti, išsiskirti bet kokioje miesto dalyje, bet kokioje pastatų apsuptyje, todẻl ugdant šiuolaikinius architektus svarbu perteikti jiems ne tik meninio komponavimo ịgūdžius, bet suvokimą, kaip architektūra gali prisidèti prie harmoningos socialinès elgsenos stereotipų aktualizavimo, ypač skatinant socialinị solidarumą (nes tai susiję su visuomenès grupių santykių harmonizavimo užtikrinimu). Todèl svarbus kompozicinių priemonių, galinčių užtikrinti harmoningos socialinės sąveikos nuostatų aktualizavimą, socialinio solidarumo nuostatų įtvirtinimą, pažinimas, o tam ypač svarbu šiuo aspektu ịvertinti mūsų šalies ịvairių laikotarpių ižymių architektų kūrybą. Vienu iš tokių architektų yra V. Landsbergis-Žemkalnis, kuriam architekto atsakomybè visuomenei buvo ypač svarbi. Architekto V. Landsbergio-Žemkalnio darbų analizè parodè, kad jo kūrybai būdingas organiškojo kompozicinio tipo vyravimas, o kartu - socialinio solidarumo programavimą užtikrinančių architektūrinių kompozicinių priemonių dominavimas. Ypač šiomis programuojančiomis savybemis pasižymi V. Landsbergio-Žemkalnio pastatai, esantys pačioje Kauno miesto širdyje - Naujamiestyje. Tai pasireiškia tuo, kad šie pastatai yra daugiau miestietiško tipo, aktyviai „bendradarbiauja“ su gretimais pastatais, su visa gatvės erdve. Tolstant nuo centro, pastatuose gausẻja vertikalių elementų, daugiau skiriasi atskirų pastato dalių aukštis, siluetas darosi aktyvesnis, dinamiškesnis. Tipologiškai tai būdingi priemiesčių ar užmiesčio pastatų, kurie pretenduoja ị lokalinio kompozicinio centro vaidmenį, bruožai. V. LandsbergioŽemkalnio kūryba liudija apie jo sugebejimą suprasti urbanistinę situaciją ir joje deramai parinkti statinio kompozicinius parametrus, ypač - tankiai užstatytoje aplinkoje, kur solidarumo vaizdinis reprezentavimas yra itin aktualus.
\end{abstract}

Reikšminiai žodžiai: V. Landsbergio-Žemkalnio kūryba, architektūrinė kompozicija, organinis kompozicinis tipas, hierarchinis kompozicinis tipas, architektūros poveikis žmogaus sąmonei, socialinis solidarumas, etika.

\section{Ivadas}

Atidžiau nagrinëjant šiuolaikinès Lietuvos architektūros procesą, galima pastebėti, kad šių dienų architektai nelabai moka pritaikyti statinius prie susiklosčiusios istorinès aplinkos $(1,2 \text { pav. })^{1}$.

Kiekvieno pastato kompozicija atskirai lyg ir patenkinama, o visuma - gatvès ansamblis - disonuojanti. Kalbant apie ši šiuolaikinių architektų kūrybinị trū- kumą būtina pabrèžti, jog be komponavimo kokybès problemų, be miestų užstatymo reglamentavimo netobulumo (šio klausimo čia nenagrinèsime), tai gali būti sietina ir su viena sociokultūrine problema. Turimas omenyje toks reikšmingas sociumo konsolidavimui veiksnys kaip socialinis solidarumas.

\footnotetext{
1 Visos nuotraukos - Vytauto Petrušonio.
} 


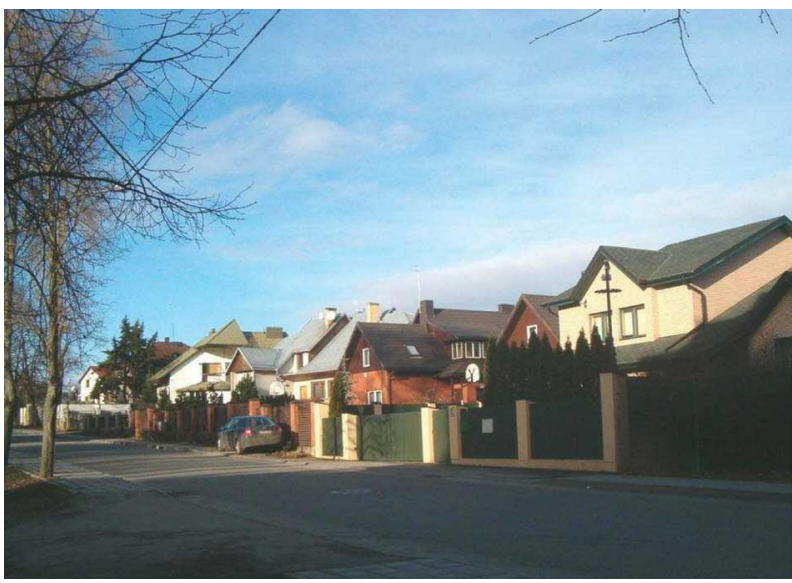

1 pav. Sodybinių namų užstatymas Kampo gatvejje Nr. 16A-24, Kaune (2007 m.)

Fig. 1. Residential housing in Kampas street No. 16A-24, Kaunas (2007)

Šiuo metu nemažai rašoma apie socialinio solidarumo eroziją šiuolaikinèje Vakarų ir Lietuvos visuomenè$\mathrm{je}^{2}$. Socialinio solidarumo tema, kuri tiesiogiai siejasi su visuomenès organizmo funkcionavimo kokybe, turi netiesioginį ryšį ir su architektūrinès aplinkos kokybiniais parametrais. Architektūriniai objektai savo kompozicinèmis ypatybèmis gali prisideti prie socialinio solidarumo jausmo skatinimo, ugdydami architektūrinę aplinką stebinčių ir joje veikiančių žmonių sąmonèje socialinès elgsenos stereotipus, susijusius su socialinio solidarumo jausmu. Kuriant architektūrą tai vyksta visų pirma demonstruojant nuostatą dèl pastato harmonizavimo su aplinka. Tam, kad galima būtų nagrinèti architektūros objektų kompozicinius ypatumus, susijusius su socialinio solidarumo reiškiniu, reikia turèti tyrimo priemonę, kuri leistu architektūriniuose objektuose nustatyti apibrěžto tipo bruožus, susijusius su socialiniu ir psichologiniu solidarumo jausmo ugdymo procesu.

Straipsnio tikslas, apibendrintai pateikiant teorines prielaidas ir pagal jas suformuluotus vertinimo kriterijus (detaliau tai jau buvo atlikta kituose autoriaus straipsniuose ${ }^{3}$ ), pademonstruoti, kaip socialinis solida-

\footnotetext{
2 Išsamią šo klausimo apžvalgą pateikia A. Guogis ir J. Bieliauskaitè (Guogis 2006; Bieliauskaitè 2009).

3 Socialinio solidarumo motyvai interpretuojami straipsnyje remiantis ankstesniais autoriaus darbais (Petrušonis 2004a, 2004b, 2005a; 2005b, 2007; Петрушонис 2006), kuriuose diferencijuojant kompozicinių tipu (sąlygiškai vadinamu „organinis" ir "hierarchinis“) potencijas aktyvuojami suvokejo sąmoneje tam tikri socialiniai elgsenos stereotipai, pateikiami kriterijai, padedantys identifikuoti meninio teksto struktūrinius elementus, aktualizuojančius vieną ar kitą socialinès
}

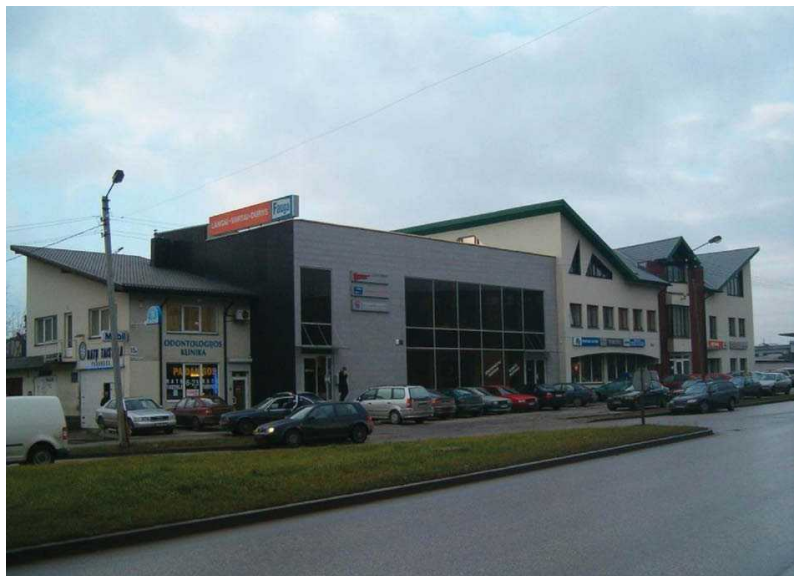

2 pav. Komercinès paskirties objektai Birželio 23-iosios gatvèje Nr. 15B, 23G, Kaune (2007 m.)

Fig. 2. Commercial buildings in Birželis 23 street No. 15B, 23G, Kaunas (2007)

rumas gali būti programuojamas konkretaus autoriaus sukurtų pastatų architektūrinėmis kompozicinèmis priemonemis. Uždaviniai - pristatyti socialinio solidarumo reiškinio esmę, apibrežti, kaip architektūra gali veikti ši reiškinị, panagrinèti, kaip mūsų tarpukario nepriklausomos Lietuvos įžymūs architektai, konkrečiai - Vytautas Landsbergis-Žemkalnis - spręsdavo pastato dermès su aplinka klausimą, kokiems paties pastato kompoziciniams sprendimams teikdavo pirmenybę vienoje ar kitoje urbanistinëje situacijoje, kaip tai siejasi su socialinio solidarumo programavimo proceso vertinimo kriterijais. Tai, kad V. LandsbergioŽemkalnio kūrybos nagrinèjimas sietinas su socialinio solidarumo tema, galima spręsti tiek iš jo samprotavimų ${ }^{4}$, tiek iš pačių jo kūrinių analizès. Pirmenybè, žinoma, teikiama kūrinių analizei. Taip yra todèl, kad straipsnio autorius ypatingą reikšmę skiria ikireflek-

sąveikos modelị. Nors kompoziciniai tipai buvo diferencijuoti remiantis Elenos Kiričenko (Кириченко 1979) darbu, svarstymai apie elgsenos stereotipų aktualizavimą atitinkamomis kompozicinèmis priemonèmis - autoriaus. E. Kiričenko siejo organiniam kompoziciniam tipui priskiriamų kūrinių idèjinès menines sistemos sąsajas su demokratizmo principais (ten pat, p. 351). Skyrelyje "Socialinio solidarumo idèja ir architektūra" pateikiami svarbiausi teiginiai iš minètų autoriaus darbų. Šiame straipsnyje daugiau dèmesio skiriama socialinio solidarumo reiškinio ir architektūrinès kompozicijos sąsajoms.

4 Tai juntama tiek jo atsiminimų knygoje (Landsbergis-Žemkalnis 2009), tiek monografijoje, nagrinejjančioje jo kūrybą (Kančienè, J.; Minkevičius, J. 1993. Architektas Vytautas Landsbergis-Žemkalnis. Vilnius: Mokslo ir enciklopedijų leidykla). Rašydamas apie Kūno kultūros rūmus V. LandsbergisŽemkalnis teigè,jog sportiškai auklëjantjaunimą bus,skiepijama tautos solidarumo, draugiškumo ir sutartinio bendradarbiavimo principai“ (cit. iš Kančienẻ 1993: 27), 
syviam suvokimo lygmeniui, kūrèjo samprotavimų neveikiamai hermeneutinei analizei. Sąvoka „socialinio solidarumo motyvai“, išryškinta straipsnio pavadinime, nurodo ị su socialiniu solidarumu sietinų kompozicinių priemonių visumą.

\section{Socialinio solidarumo idèja ir architektūra}

Socialinio solidarumo (neretai minimo kartu su socialiniu teisingumu) reiškinys, kokybè, principas šiuo metu yra kaip savotiškas idealas, siekiamybé ${ }^{5}$. Socialinis solidarumas yra vienas iš pagrindinių principų, kuriuo remiasi socialine teisinè valstybè ir kuris išreiškia visuomenès narių santykių kokybę. Žmogaus teisių socialineje teisineje valstybejje užtikrinimas yra neatsiejamas nuo socialinio stabilumo vertybės. Solidarumui, kaip visuomenès stabilumo palaikymo priemonei, gali turèti įtakos instrumentiniai, individualistiniai ar vertybemis bei socialiniais jausmais grịsti motyvai (Bieliauskaitè 2009: 79).

Aptaręs socialinio solidarumo reiškinio raidą, jo sustiprëjimo ar susilpnëjimo atskirais XX a. istoriniais etapais aspektus, krizes ir peripetijas Arvydas Guogis pabrèžia šio reiškinio svarbą ir ateityje. Nors jis savo dèmesị sutelkęs ị socialinès apsaugos lauką, tačiau su pasididžiavimu pristato unikalią Baltijos šalių patirtį: „Taip Baltijos šalys, nepaisydamos sustiprejusių pasaulinių individualizmo tendencijų 9-ojo ir 10-ojo praejusio amžiaus dešimtmečių sandūroje, savo nacionalinio atgimimo sąjūdyje pademonstravo reikšmingus socialinio solidarumo ir altruizmo pavyzdžius. Nors vèliau

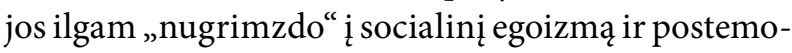
cionalizmą, pirmieji XXI amžiaus metai Baltijos šalyse ir Lietuvoje vèl žymi bendruomeniškumo tendenciju sustiprẻjimą ir didesnị socialinio solidarumo poreikị. Tai liudija ne tik gerokai išaugusios valstybinès socialinès apsaugos socialinès išmokos, bet ir bendruomeninių organizacijų ikūrimas ir veikla siekiant jungiančių, o ne skiriančių rezultatų“ (Guogis 2006: 12).

Solidarumo terminas yra kilęs iš lotynų kalbos žodžio solidare - sutvirtinti, suderinti dalis taip, kad jos suformuotų tvirtą visumą; jis apibūdinamas kaip bendramintiškumas, vieningumas, interesų bendrumas, bendra atsakomybè, tarpusavio parama (Bieliauskaite 2009: 81).

\footnotetext{
Pavyzdžiui, Lietuvos Respublikos Prezidentès tinklalapyje socialinis solidarumas tiesiogiai tapatinamas su "tautos vienybe ir stiprybe“. Teigiama, jog „socialinis teisingumas ir solidarumas - visuomenès moralumo ir išminties matas, jos stiprybès kertinis akmuo. Turime puoselèti šią vertybę - tautos išlikimo garantą“" (Grybauskaitè 2010).
}

A. Guogis solidarumo traktuotès kitimą, sekdamas užsienio šalių autoriais, sieja su postemocionalizmo įsigalèjimu. Postemocionalizmas kaip reiškinys atspindi tendenciją, kad jausmai intelektualizuojami, o ne jaučiami; jis siejamas su manipuliavimu valdant jausmus. Visa tai skatina dirbtinès, ne autentiškos civilizacijos kūrimą (Guogis 2006: 11). Mes sietume tai su „gyvenimo neigimu“, kurị aprašè E. Fromas (Фромм 1992).

Socialinio solidarumo kaitos veiksniai yra labai įvairūs, jie sietini su tokiais reiškiniais kaip individualizacija, diversifikacija, globalizacijos procesas, segmentacija. Individualizacija siejama su pilietiškumo korozija ir dezintegracija. Antrasis veiksnys, turintis itakos solidarumo transformacijai, - identiškumo, preferencijų, ịsitikinimų ir ịsipareigojimų diversifikacija. Z. Baumano manymu, svetingumas atvykèliams yra pirminè solidarumo forma. Tačiau moderniosiose Vakarų gerovès valstybėse originali svetingumo sąvokos prasmè pasikeitè. Svetingumas atvykèliams, kažkada visame pasaulyje buvęs moraline pareiga ir kasdiene praktika, prarado savo pirminę solidarumo išraiškos prasmę (Bieliauskaitė 2009: 90).

Trečiasis solidarumo sampratos pokytis siejamas su globalizacijos procesu. Globalizacijai būdingą mobilumą Z. Baumanas sieja su vengimu pareigos prisidèti prie kasdienio gyvenimo ir išsaugoti bendruomenę. Sociologo teigimu, tarptautinès korporacijos sutinka mokèti vietos mokesčius joms reikalingiems keliams tiesti ar nuotekų ịrenginiams remontuoti, tačiau jos „nematančios reikalo moketi už vietinių bedarbių, neiggaliųjų ar kitų žmogiškųjų išteklių išlaikymą, nes nesijaučia nẻ kiek atsakingos už jų likimą ar dèl to ịsipareigojusios" (Bieliauskaitè 2009: 90).

Pastaruoju metu aktyviai veikiant minètiems veiksniams (individualizacijai, diversifikacijai, globalizacijai ir segmentacijai) pastebima socialinio (kartų) solidarumo nykimo tendencija. Tai kelia pavojų pačios socialinès teisinès valstybès egzistavimui, nes socialinis visuomenès narių solidarumas yra svarbus socialinès teisinès valstybès stabilumo ir efektyvaus funkcionavimo garantas, padedantis ịveikti socialinę itampą, kurią gali sukelti šios valstybès intervencija ị tam tikras gyvenimo sritis (Bieliauskaitė 2009: 92) ${ }^{6}$.

A. Guogis ir J. Bieliauskaitè pristato solidarumą pabrèždami ekonominius ir teisinius aspektus. Tačiau

\footnotetext{
6 Šiame straipsnyje socialinis solidarumas nesiejamas tik su kartụ solidarumu, kaip kad tai dažniausia suprantama socialinės teisinès valstybès ypatumus atskleidžiančioje literatūroje, o turimas omenyje bendresnis visuomenès solidarumas.
} 
ekonominiai aspektai yra antriniai. Subjektyvus momentas, pažiūrų sistemų vaidmuo socialinio solidarumo tapsmo kontekste yra lemiamas. Visa XX amžiaus istorija liudija, kad dauguma nelaimių nulemta subjektyvių veiksnių. Vienas jų - specifinis mąstymas, pasižymintis supaprastintu požiūriu į aplinką, kai psichologiškai grịsta konfrontacija iš asmens sąmonès sferos iškeliama ị išorinị pasaulị. Iš to - destrukcinès nuostatos, kurių pasekmès: karai, revoliucijos, totalitariniai režimai, socialinè ir nacionalinè nesantaika.

Architektūra visada atliko ideologinị vaidmenį savo formomis, vaizdiniais modeliavo pasauli, pagrịstą tam tikromis socialinès sąveikos idèjomis, reprezentavo tam tikrus sektinus modelius, savaip interpretavo socialinio solidarumo idèją. Amerikiečių sociologo L. Mayhewo teigimu, solidarus elgesys atsiranda tam tikrose institucijose, kurias jis vadina „solidarumo sistema“. Tokios institucijos pavyzdys yra šeima, kuri nustato ir modeliuoja patrauklumo, antipatijos, lojalumo ir identiškumo visuomenèje šablonus (Bieliauskaite 2009: 83). Pratęsiant jo mintị architektūrinę kompoziciją taip pat galima apibrèžti kaip savotišką ,,solidarumo sistemą", kaip vaizdiškai operuojantị solidarumo modelio koreliatą, projekciją. Tokia sistema taip pat modeliuoja antipatijos, lojalumo ir identiškumo visuomenèje šablonus.

Solidarumas gali būti puoselëjamas dvejopai. Viena, kai asmens ir visuomenès santykiai harmonizuojami per kultūrą, ,etinès mistikos" ${ }^{\text {"7 }}$ sąlygomis (vertybès bendros ir individualios, bendri ir individualūs interesai sudaro darnią visumą); kita, kai asmens ir visuomenès santykiams tvarkyti prioritetiškai pasitelkiama valstybė, kai visuomenès interesus uzurpuoja valstybès interesai, akcentuojamas tapatumas su autoriteto vertybèmis (šiam atvejui tiktų A. Šveicerio terminas „tapatumo mistika“).

Mums pagrindinis prasminis solidarumo dèmuo tai bendradarbiavimas, kuris remiasi ne tiek paklusnumu tiesioginiams direktyviniams nurodymams, o pagristas asmenine iniciatyva veikiant kartu ir savo, ir bendruomenès labui. Direktyvinis vienybès kultivavimo modelis būdingas daugiau totalitarinèms valstybèms, o bendradarbiavimu, ịvairių socialinių grupių konsensusu pagrịstas socialinis solidarumas sietinas su demokratinèmis valstybėmis. Totalitarinio režimo atveju solidarumas pagrịstas ne bendradarbiavimu, o prievarta, sąmonès manipuliavimu. Demokratinejje visuomeneje socialinis solidarumas pagristas savano-

\footnotetext{
A. Šveicerio terminas (Швейцер 1988).
}

riška nuostata. Apskritai socialinio solidarumo sąvoka daugiau siejama su demokratinès valstybès modeliu.

Dar 1800-aisiais Vilhelmas Humboltas (Wilhelm Humboldt, 1767-1835) pasiūlè visuomenès ir individo sąveikavimo būdą ne policinès valstybès priemonèmis (kurios dažniausiai paremtos prievarta), o per kultūrą, kuri ugdo atsakingumą (Кильен 1983). 200 metų liudija, kad jis galbūt buvo teisus, manydamas, jog toks būdas etiškai labiau pagrịstas. Valstybè, nors pati yra visuomenès ir kultūros kūrinys, bet kai tiesiogiai imasi reguliuoti visuomenès gyvenimą, ji dažniausiai siekia unifikuoti visuomenès narius, nes jai taip patogiau. $\mathrm{O}$ tai priešinga kultūros tikslams, nes kultūrai svarbu žmonių, visuomeninių grupių ỉvairovè. Kultūra - tai siekimas išvengti visuomenès suskaidymo, susvetimèjimo. Eksteriorizacija - atsivèrimas pasauliui be susvetimejjimo - štai kas yra kultūra. Anot V. Humbolto, toks atsiverimas yra aukščiausias žmogaus gyvenimo tikslas.

Socialinio solidarumo idèja sietina su kultūros, kaip ją suprato Wilhelmas Humboldtas, traktuote. Tokiu atveju kultūrai skiriamas ypač svarbus vaidmuo, apribojant valstybės kaip policinès priemonès vaidmenį.

Sociokultūriniu požiūriu, ị architektūrinès kompozicijos problemą galima žvelgti remiantis dviem kultūros koncepcijomis, išskiriamomis kultūrologijoje, kaip tam tikrais apibendrintais aplinkos projektavimo metaprincipais: „,represinès kultūros" (kai laikoma, kad kultūra turi sutvarkyti pasaulį taip, kad būtų negalimos jokios nesankcionuotos spontaniškumo apraiškos) ir "multikultūrinį“" (kai akcentuojamas skirtingų spontaniškų raiškų lygiateisiškumas). Abi koncepcijas atitinka apibrèžtas sąmonès tipas.

Labiau siekiamu, labiau „ekologiškai“ motyvuotu, ittvirtinančiu gyvenimo teigimą, reikètų pripažinti „multikultūrinį“ metaprincipą. Vyraujant „represinès kultūros" metaprincipui, architektūrinejje kompozicijoje neretai ikūnijama dominavimo, atpildo, keršto, socialinio supriešinimo, atribojimo ideologine programa. Multikultūralizmo atveju laikomasi kitų principų. Pirmenybė ne išskirtinumas, supriešinimas, o bendradarbiavimas.

Architektūrinès kompozicijos ideologinè programa yra dešifruojama suvokejjui stebint ar prisimenant objektą. Socialinès komunikacijos plotmejje kompoziciją patogu traktuoti kaip tekstą, susidedantį iš intekstų prasminių požiūriu prisodrintų teksto dalių, susietų su kitais išoriniais tekstais - metatekstais (terminai vartojami semiotikoje). Intekstai atpažistami remiantis bendrąja kolektyvo atmintimi. 
Tekste intekstai perteikia metatekstus - tropais, dažniausia metaforomis ar metonimijomis išreikštus vaizdinius, aktualiai (ar tariamai aktualiai) susijusius su realiu gyvenimu. Tuose vaizdiniuose fiksuojamos vaidmeninès situacijos ${ }^{8}$, kur tarp įvairių subjektyviu dalykų (asmenų, idejų, simbolių ir pan.), išreikštų meniniame vaizde, yra nusistoveję vieno ar kito tipo santykiai. Santykiai vaidmenineje situacijoje perteikiami per vaidmeninę struktūrą. Jos gali būti skirstomos pagal vyraujančius santykių tarp žmonių tipus: bendradarbiavimas, atpildas, viešpatavimas, atsiribojimas". Mažiausia galimybių rinktis yra atpildo, pajungimo (kai kažkas viešpatauja arba yra pajungtas), atribojimo (izoliacijos) vaizdiniais pasižyminčiose vaidmeninèse situacijose. Jos pasižymi kraštutiniu polemizmu. Priešingas polemizmui polius - harmonizmas ${ }^{10}$, kai prioritetas skiriamas bendradarbiavimui, sąveikai, o ne vienapusiam poveikiui.

Kompozicijos ideologinès programos tipą lemia vyraujantis vaidmeninès struktūros tipas, ịkūnytas meniniame vaizde. Vaidmeninè struktūra ịtvirtina atitinkamą pasaulio modelį. Kai stebètojo sąmonëje vieno tipo metatekstų „mirgejjimas“ suvokimo akimirką viršija kito tipo metatekstų poveikị, ịvyksta gyvenimiškos pozicijos, susijusios su atitinkamu pasaulio modeliu, pasirinkimas. Gyvenimišką poziciją nulemiant polemizmu grịstam pasaulio modeliui, suvokejo sąmonèje aktualizuojasi poleminès elgsenos stereotipai, kitu atveju aktualizuojasi harmoninès elgsenos stereotipai.

Polemiškai nusiteikusio aplinkos atžvilgiu žmogaus sąveika su aplinkiniu pasauliu ir pačiu savimi yra apsunkinta, nes jo sąmoneje susiformuoja pasaulio modelis, ịtvirtinantis tokią vaidmeninę struktūrą, kuri grindžiama idejja, jog skirtingų subjektų interesų derinimas neįmanomas ir netikslingas. Paprastai tai būna, kai santykiai tarp subjektų apibrèžiami antihumanistiniais karo, kovos vaizdiniais. Visuomenè, kurioje dominuoja tokios pažiūros, yra pasmerkta „nenuobodžiam“, pilnam socialinių konfliktų gyvenimui. Apie normalų ekonomini gyvenimą kalbèti netenka, nes atmetama tam būtina bendradarbiavimo idejja.

Polemika pagrịstų elgsenos stereotipų (jie, beje, labiausiai atitinka represinès kultūros sąmonès tipą) skatinimu pasižymi architektūrinès kompozicijos, turin-

\footnotetext{
8 Vaidmenine situacija reprezentuoja „paviršinę" raiškos (varianto) plotmę, o vaidmeniné struktūra - „gilumine“" (sistemos; invarianto) plotmę. Ši pora atitinka tai, kas lingvistikoje apibrèžiama kaip „šneka“" (atskiras tekstas) ir „kalba“ (kodas).

9 M. Rašo suskirstymas (Раш 1991).

${ }^{10}$ Abi sąvokos A. Liubiščevo (Любищев 1977).
}

čios savybių, kurias sąlygiškai galima būtų pavadinti „hierarchinèmis“. Multikultūralizmo - simbiozès, harmoningos sąveikos skatinimo požiūriu, priimtinesni kitokio tipo kompoziciniai sprendimai. Pavadinkime juos atitinkantị kompozicinį tipą „organiniu“. Jis veikia aplinkos ansamblio principu. Šio tipo kompozicijos atviros aplinkai, jos organiškai ịsilieja ị kontekstą (tiek urbanistini, tiek konceptualų). Šis aplinkos formavimo metaprincipas turètų būti pripažintas baziniu.

„Hierarchinès“ kompozicijos ịkūnija viešpatavimo, diktato vaidmenines situacijas, o „organinès“ bendradarbiavimą. Abiejų tipų kompoziciniai tikslai yra orientuoti priešingai. Tačiau jų priešiškumas nèra simetrinis. İ didesnị organinị tekstą mažesnis hierarchinis tekstas gali įeiti, bet atvirkščias principas negalioja. Mat, hierarchinis tekstas yra iš principo monologinis, jis linkęs dominuoti, jis nepakenčia kitatikių. Tačiau, jei jam yra skiriama tinkama vieta (tinkama ne jo paties, o konteksto požiūriu), jis patenkinamai atliks misiją - bendradarbiavimo ideją̨ išreikš lokaliai, ribotai pabreždamas jam mielą viešpatavimo, dominavimo temą. Hierarchiniai tekstai linkę dominuoti dèl savo reguliarumo (ašinè simetrija, pabrèžtas vertikalumas, kitos hierarchinio tipo meninio vaizdo dalys). Architektūriniam ansambliui šios savybės suteikia dramatizmo, padidina ansamblio intekstų derinio (kai ansamblyje yra ir "hierarchinių“, ir „organinių“ elementų) paradoksalumą, taip reikalingą pajusti pirmapradei būsenai (kai architektūrinio kūrinio stebètojas užmiršta viską ir tarsi „gimsta“ kitoks, apsivalęs, atsinaujinęs, apsisprendęs). Tačiau hierarchiniai elementai negali vienašališkai uzurpuoti ansamblio kompozicinio centro vaidmens.

Ar pastato kompozicinis tipas hierarchinis, ar organinis, gali padèti nustatyti kontroliniai klausimai (kai atsakymo variantas „taip“, skliausteliuose nurodytas kompozicinis tipas: „O“ - organinis, „H“ hierarchinis $)^{11}$ :

1. Jei fasade yra rizalitų, ar jie vainikuojami bokšteliais ir kupolais? $(\mathrm{O})$

2. Jei pastatas susideda iš keleto dalių, ar jos visos skirtingo aukščio? (H)

3. Ar fasade yra erkerių? (O)

4. Ar pastatui būdingas dalijimas ị cokolį, pagrindinị tūrị, vainikuojančią dalį? $(\mathrm{H})$

5. Ar langai sugrupuoti įvairiai kintančiu žingsniu? (O)

${ }^{11}$ Didžioji testo klausimų dalis suformuluota ịvertinant organinio ir hierarchinio kompoziciniu tipu apibūdinimus, kuriuos pateikè rusų menotyrininkè E. Kiričenko (Кириченко 1979). 
6. Ar pastato fasado kompozicija, taip pat angų išdèstymas simetriniai-ašiniai? $(\mathrm{H})$

7. Ar ryškus horizontaliai besivystančių ritmų vyravimas? $(\mathrm{O})$

8. Jei pastatas sudarytas iš atskirų tūrių, ar jų grupavimui būdinga simetrija? $(\mathrm{H})$

9. Ar meniški elementai užgožia praktiškai naudingus (nelygiaverčiai jiems)? (H)

10. Ar ryški hierarchinè pastato elementų subordinacija? $(\mathrm{H})$

11. Ar pastato kompozicija gali būti visiškai suvokta iš vieno stebèjimo taško? $(\mathrm{H})$

12. Ar ritmas turi antraeilę, priklausančią nuo simetrijos reikšmę? $(\mathrm{H})$

13. Ar būdinga keleto skirtingos prigimties ritminių eilių aktyvi ritmika? (O)

14. Ar pastate ịkūnyta projektavimo nuo išorès ị vidụ nuostata? (O)

15. Ar pastato simetrinè kompozicija traktuotina kaip išvestinè iš ritminès? $(\mathrm{O})$

16. Ar ryškus metro priklausymas nuo simetrinèsašinès, o ne ritminès kompozicijos? $(\mathrm{H})$

17. Ar yra lygiagretus keleto temų vystymas fasado kompozicijoje? (O)

18. Ar pastato savarankiškumas paaukojamas siekiant gatvès erdvès, aplinkos visumos? $(\mathrm{H})$

Naudojant šį testą galima ịvertinti, kaip rengiamas projektas, ar igyvendintas objektas gali prisideti prie socialinio solidarumo nuostatų ugdymo. Tokị testą galima naudoti ir rengiant rekonstrukcijos projektus ${ }^{12}$.

\section{Socialinio solidarumo programa}

\section{Landsbergio-Žemkalnio kūriniuose}

Kaipgi su socialinio solidarumo aktualizavimu susijusios architektūrinès išraiškos priemonès, ¡̨kūnytos V. Landsbergio-Žemkalnio kūriniuose? Bus trumpai pristatyti jo kūriniai, o vèliau pagal išdèstytus organinio ir hierarchinio kompozicinio tipo atpažinimo kriterijus bus atliktas vertinimas.

Straipsnyje bus nagrinejjama tik dalis V. Landsbergio-Žemkalnio kūrinių. Buvo atrinkti tik realizuoti pastatai, aktyviai veikiantys aplinkoje. Nagrinejjami stambesni objektai, turintys visuomeninę ar gamybinę paskirtị. Kaip išimtis įtrauktas nunciatūros pasta-

\footnotetext{
${ }^{12}$ Nustačius planuojamo rekonstruoti pastato kompozicinį tipą taip pat rekonstrukcijos projekte atvaizduoto pastato tipą, galima sužinoti, koks kompozicinis tipas bus po rekonstrukcijos. Sociokultūriniu požiūriu svarbu bent išsaugoti esamą kompozicinị tipą (tai gali būti susiję su motyvuotais kultūros paveldo apsaugos reikalavimais). Keisti organinį kompozicinị tipą Ł̇ hierachinị reikia labai atsargiai.
}

tas, nes buvo numatytas Vatikano atstovui, o tai jau visuomeninès reikšmès reikalas. Gal - visuomeninès paskirties objektas.

Kauno centre esantys objektai: Universiteto akių ir ausų ligų klinika (1929), „Pienocentro“ rūmai (19311934), Apskrities savivaldybès rūmai (1935), Prekybos, pramonès ir amatų rūmai (1937), Vatikano pasiuntinio rezidencija (1930); toliau nuo centro yra šie objektai: Kūno kultūros rūmai (1931-1933), Tyrimų laboratorija (1932-1936), „Pienocentro“ centrinè pieninè (1935). Pastatus autorius apžiūrèjo natūroje, apibūdindamas naudojosi tiek savo, tiek nuodugniai tyrinejjančios Kauno tarpukario architektūrą Jolitos Kančienès apibendrinimais, pateiktais ịvairiuose leidiniuose.

Universiteto klinikos (3 pav.) išore paprasta, fasado struktūrą pabrèžia horizontalios juostos (cokolio, tarpaukščių, pastogès).

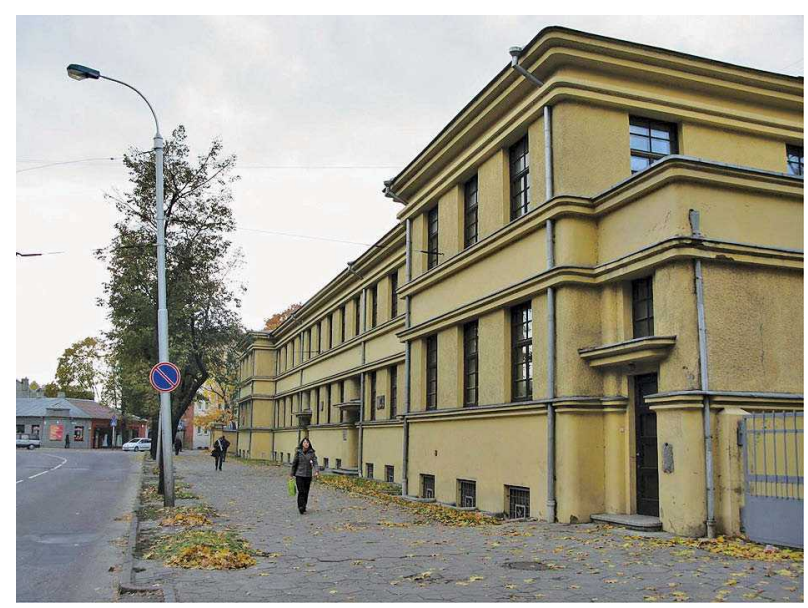

3 pav. V. Landsbergis-Žemkalnis. Kauno universiteto akiu ir ausų ligu klinika, $1929 \mathrm{~m}$.

Fig. 3. V. Landsbergis-Žemkalnis. Ophthalmotologal Clinic of Kaunas University, 1929

„Pienocentro" bend rovès rūmai (4 pav.) stovi nedideliame sklype prie sankryžos, sudaro vientisą apstatymą su abiejomis gatvemis; plytų sienos sumūrytos ant gelžbetoninių pamatų, sutvirtintos metalinemis kolonomis; architektūra išsiskiria apibendrintu tūriu; tolygiais tarpais išdèstytus centrinès dalies langus horizontaliai jungia palangių traukos; pastato viršu juosia profiliuotas karnizas (Kančienè 1991b: 143). Pastatas, anot J. Kančienès, traukia abstrahuotu paprastumu: „ritmas, nepriekaištingos proporcijos, vertikalių ir horizontalių pusiausvyra buvo svarbiausios meninès išraiškos priemonès" (Kančienè 1993: 27). „Pirmasis aukštas išsiskyrè didelèmis vitrinomis, 


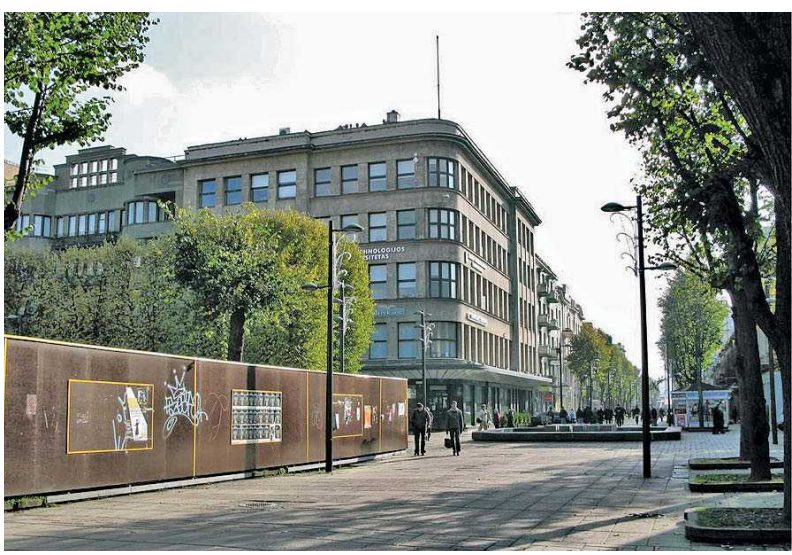

4 pav. V. Landsbergis-Žemkalnis. „Pienocentro“ rūmai, Kaunas, 1931-1934 m.

Fig. 4. V. Landsbergis-Žemkalnis. Pienocentras House, Kaunas, 1931-1934

juodo labrodarito apdaila, šviečiančiu stiklo stogeliu; dar viena subtili detale - išlenkti kampiniai langai“ (ten pat).

Nepaisant to, jog tai aukščiausias Laisvès alëjos pastatas, horizontalūs kompoziciniai elementai neleidžia jam „išsišokti“. Horizontalumą pabrèžia didelèmis vitrinomis išsiskiriantis pirmasis aukštas ir nuo viso fasado ji skiriantis platus, plokščias stiklo stogelis.

Apskrities savivaldybė (5 pav.) - būdingas Kauno „administracinès architektūros" pastatas, kurio struktūrą lèmè kampinè situacija; griežta, net sausoka architektūrinè išraiška atitiko rūmų paskirtị; abiejų korpusų fasadai traktuoti vienodai, kaip pagrindiniai, bemaž analogiškos jų kompozicijos (Kančienè 1993: 29).

Prekybos, pramonès ir amatų rūmai (6 pav.) stovi siaurame sklype dviejų gatvių sankryžoje. Tai du stačiu kampu sujungti triaukščiai korpusai; mūrinio pastato išorè nutinkuota granitiniu tinku; eksterjero kompozicija pagrịsta ritmo sąskambiu; fasaduose atskirtas horizontaliomis granito juostomis apdailintas cokolis; stogus slepia profiliuotais karnizais užbaigti parapetai; pagrindinis fasadas beveik simetriškas (Kančienè 1991a).

Nunciatūros pastatas (7 pav.), anot italų žurnalisto G. Salvatori, „grakšti, koketiška, panirusi žalumynuose vila" (Kančienė 1993: 26). J. Kančienè teigia, kad tai pirmasis ir bene vienintelis pastatas, projektuotas specialiai pasiuntinybei; didelis šio pastato pranašumas - tai jo itterpimas, tiesiog , itauginimas“ $i$ aplinką, $\mathfrak{i}$ Žaliakalnio šlaitą: prie vilos architektas numatè terasas, sienutes, laiptus, tvora; pastato sandara eksterjere atsispindi laisva, asimetriška tūrių kompozicija (ten pat).

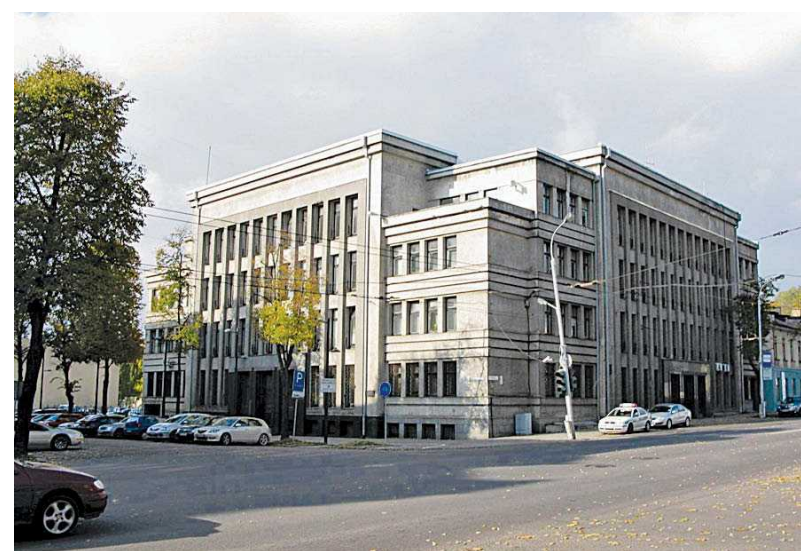

5 pav. V. Landsbergis-Žemkalnis. Apskrities savivaldybès rūmai, Kaunas, $1935 \mathrm{~m}$.

Fig. 5. V. Landsbergis-Žemkalnis. District Municipality, Kaunas, 1935

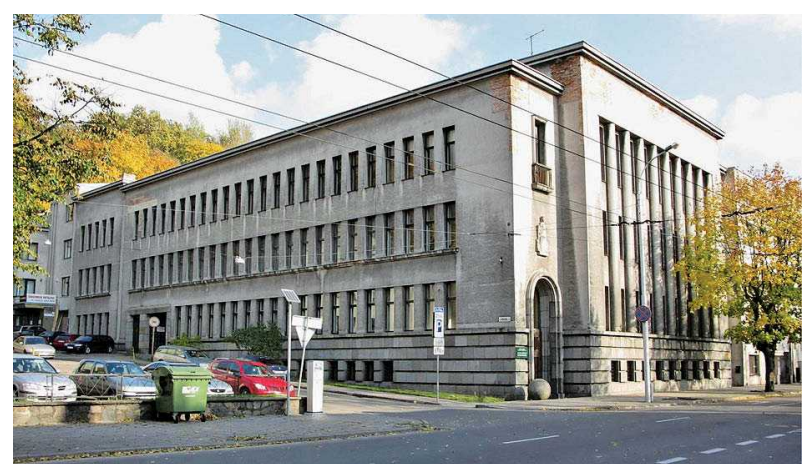

6 pav. V. Landsbergis-Žemkalnis. Prekybos, pramonès ir amatų rūmai, Kaunas, 1937 m.

Fig. 6. V. Landsbergis-Žemkalnis. Chamber of Commerce, Industry and Crafts, Kaunas, 1937

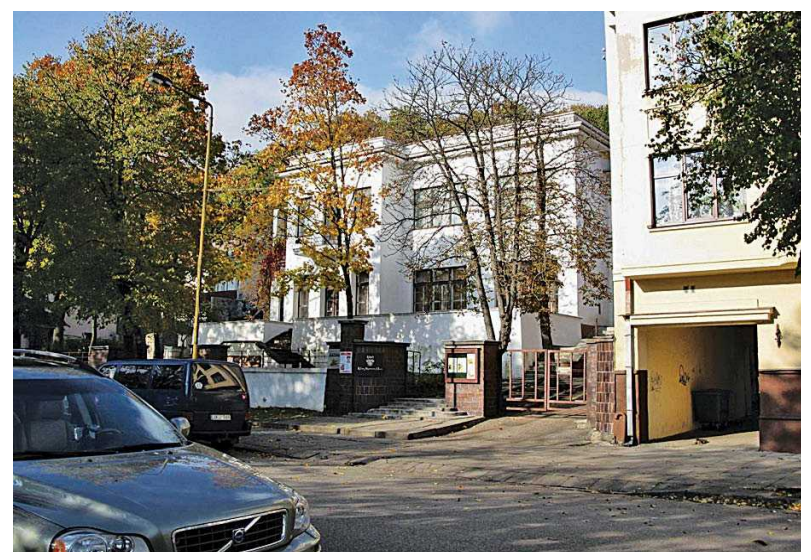

7 pav. V. Landsbergis-Žemkalnis. Vatikano pasiuntinio rezidencija, Kaunas, $1930 \mathrm{~m}$.

Fig. 7. V. Landsbergis-Žemkalnis. Nunciature - residence of the ambassador of Vatican, Kaunas, 1930 
Kūno kultūros rūmai (8 pav.) yra Kauno centriniame sporto komplekse, išplitusiame teritorijoje tarp Ąžuolyno ir Sporto gatvių bei Perkūno alejos; pastato sienos iš plytų; šiaurinis fasadas simetriškas - centrine dalis aukštesnè ir kiek išsikišusi; siauri aukšti langai vienodais tarpais skaido sienų plokštumas; centrinejje dalyje jie sujungti siauromis tarplangių vertikalemis (Kančienè 1991c).

Tyrimų laboratorijos pastato (9 pav.) konstrukcija - apmūrytas plytų sienomis gelžbetoninis karkasas ir gelžbetoninès perdangų plokštès; pastatas komponuojamas iš aiškių geometrinių formų, jo sprendimas simetriškas; pagrindinį fasadą skaido juostiniai langai, ¿ jų horizontalią slinktị centre įsikerta siaurais langais vertikaliai sudalintas rizalitas su įtrauktu pagrindiniu ièjimu; svarbus architekto nuopelnas yra jautri sąsaja su apsuptimi (Kančienè 1991d: 288, 289).

„Pienocentro“ centrinès pieninès pastatas (10 pav.) pasižymi vertikalių kompozicinių elementų gausa, kai kurie fasadai turi laužytą siluetą.

Analizuojant V. Landsbergio-Žemkalnio kūrinius, atpažinti organinị kompozicinị tipą, sietiną su socialinio solidarumo programavimu, galima operuojant tokiais supaprastintais rodikliais:

- pastato kompozicijoje ryškus formų horizontalu-

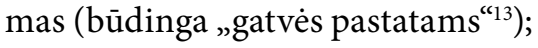

- didesnis dèmesys asimetrijai;

- vienodas arba nedaug varijuojantis pastato daliu aukštis;

- keleriopa varijuojanti tos pat paskirties kompozicinių elementų raiška (parafrazavimas);

- keleto paralelinių temų sklaida;

- ritmo, o ne metro vyravimas.

${ }^{13}$ Gatvés pastatu (arba miestietišku pastatu) vadinamas toks pastatas, kurio kompozicija, ritmika sietina ne tik su pačiu pastatu, bet ir su bendru gatvès kompoziciniu lauku. Gatveje susipina dviejų tipų savarankiški ritmai ir masteliai: „privatus“, sietinas su namu, jo elementais, kitas - bendrinis, sietinas su gatvès ir net miesto masteliu (Кириченко 1979: 337). Pastato integravimo ị gatvès erdvę principą Kiričenko tiesiogiai sieja su organiniu kompoziciniu tipu. Tokiam tipui būdingą kompozicijos atvirumą užtikrina ritmingumas, pastato akcentų pasikartojamumas, prisidedantis prie ašinės simetrijos poveikio susilpninimo (ten pat, p. 306). Vienodas aukštų (tarpsnių) aukštis kartu su pabrežntinai horizontaliai besivystančiu ritmu, horizontalumas suponuoja galimybę fasadams tęstis ị šalis lygiagrečiai su gatvès trasa (ten pat). Tokiu atveju fasade išryškejjusios kelios temos varijuojamos gretimuose namuose (rizalitais, langokraščiais, piliastrais, erkeriais ir pan.); gatvès ansamblyje atsiranda paralelinių temų, vieno pastato elementų ritmą perima kiti pastatai, jis ịsijungia i s suformuotą tankiai vienas prie kito stovinčiu pastatų, bendrą visai gatvei judejimo gilyn ir tolyn ritmą (ten pat, p. 308). Tai labai skiriasi nuo atskirai stovinčio „paviljoninio" pastato, kuris yra erdvioje, laisvoje, daugiau miesto pakraščiui ar net užmiesčiui būdingoje aplinkoje. Tokiu būdu "gatvès pastatas" veikia kartu su kitais, greta stovinčiais pastatais, skatindamas didesnio mastelio visumos suvokimą.

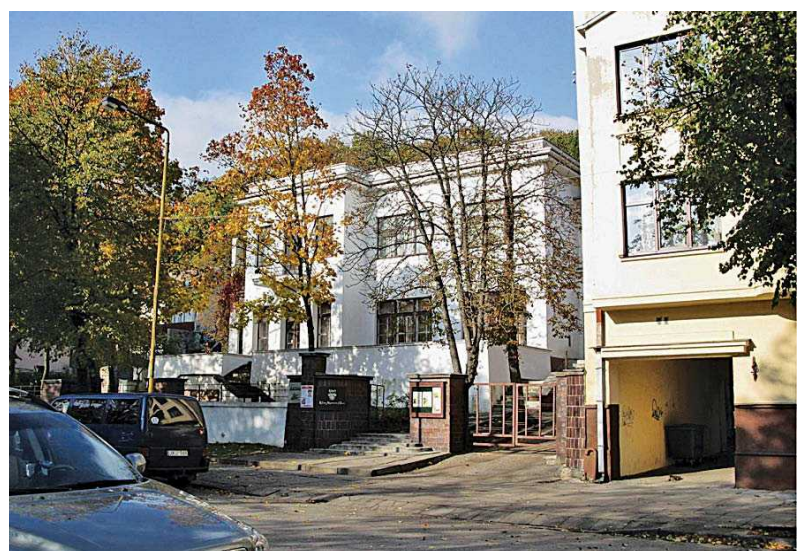

8 pav. V. Landsbergis-Žemkalnis. Kūno kultūros rūmai, Kaunas, 1931-1933 m.

Fig. 8. V. Landsbergis-Žemkalnis. Palace of Physical Culture, Kaunas, 1931-1933

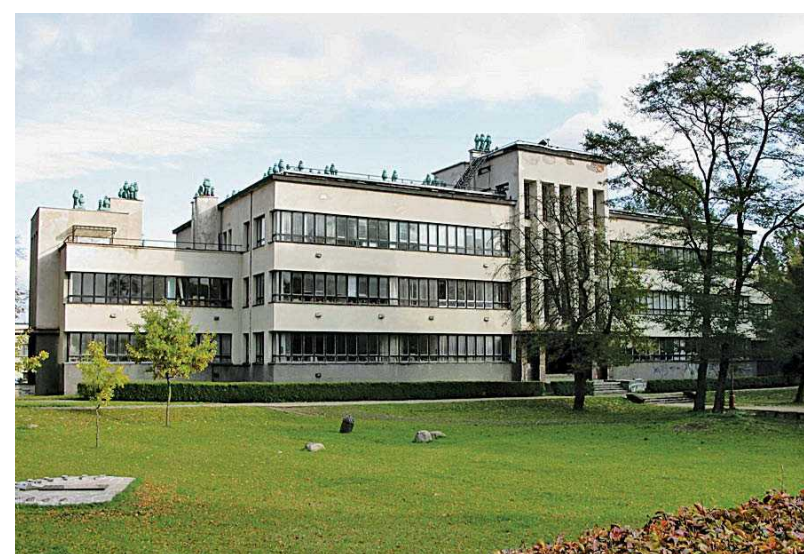

9 pav. V. Landsbergis-Žemkalnis. Tyrimų laboratorija, Kaunas, 1932-1936 m.

Fig. 9. V. Landsbergis-Žemkalnis. Research Laboratory, Kaunas, 1932-1936

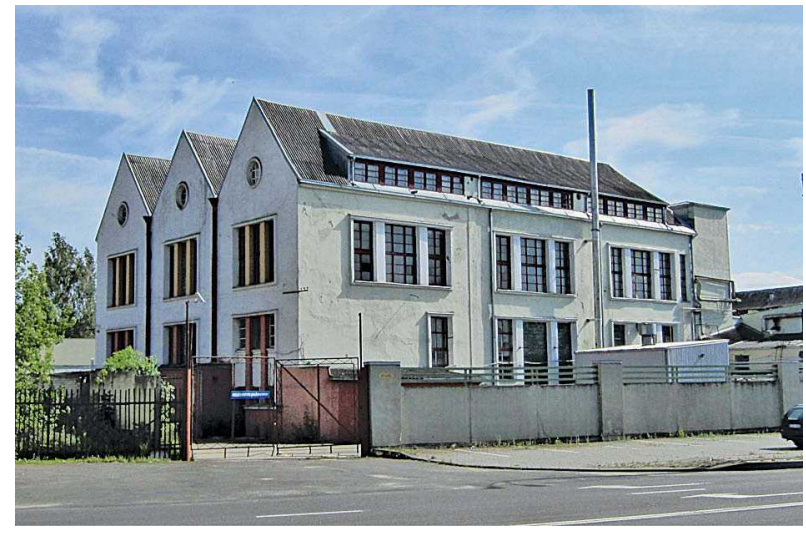

10 pav. V. Landsbergis-Žemkalnis. „Pienocentro“ centrinè pieninè, Kaunas, $1935 \mathrm{~m}$.

Fig. 10. V. Landsbergis-Žemkalnis. Central dairy of Pienocentras, Kaunas, 1935 
Atlikta analizé parodè, kad architekto V. Landsbergio-Žemkalnio darbams būdingas organiškojo kompozicinio tipo vyravimas. Ypač organiškajam kompoziciniam tipui būdingomis savybèmis pasižymi pastatai, esantys pačioje miesto širdyje - Naujamiestyje: Universiteto klinika, „Pienocentro“ rūmai, Apskrities savivaldybès rūmai, Vatikano pasiuntinybè. Tai pasireiškia tuo, kad šie pastatai yra daugiau miestiško tipo, aktyviai kompoziciškai „,bendradarbiauja“ su gretimais pastatais, su visa gatvès erdve.

Tolstant nuo centro („Pienocentro“ centrinè pieninè, Kūno kultūros rūmai, Tyrimų laboratorija) galima pastebèti, kad šalia organiškojo kompozicinio tipo požymių pastatuose atsiranda tam tikra dalis hierarchiniam kompoziciniam tipui būdingų elementų: gausèja vertikalių elementų, skiriasi atskiru pastato dalių aukštis, siluetas darosi aktyvesnis, dinamiškesnis. Tipologiškai tai būdingi priemiesčiu ar užmiesčiu pastatų, kurie pretenduoja ị kompozicinio centro vaidmenį, bruožai. Pastatams, esantiems toliau nuo miesto centro ir apžvelgiamiems iš įvairių pusių, siluetas pasirenkamas labiau laužytas, jame didesnis ir vertikalių elementų vaidmuo. Kai kurie objektai statomi ant ašies - Tyrimų laboratorija ant Vydūno al. ašies. Tai jau gana ryškus hierarchinio kompozicinio principo pasireiškimas.

\section{Išvados}

1. Šiuolaikinèje visuomenejje didejja atskirtis, socialinių grupių nesusikalbëjimas, užsisklendimas kuriant grupinius idealus, siekiant nereikšmingų tikslų. Greta kitų dalykų, tai susiję su socialinio solidarumo kaita, kuri veikiama tokių šiuolaikinès civilizacijos reiškinių kaip individualizacija, diversifikacija, globalizacijos procesas, segmentacija.

2. Šiuolaikinès kartos architektų, kartu su užsakovais esančių savojo laikotarpio atstovais, darbai ypač dažnai atspindi sieki dominuoti, išsiskirti bet kokioje miesto dalyje, bet kokioje pastatų apsuptyje, todèl ugdant šiuolaikinius architektus svarbu perteikti jiems ne tik meninio komponavimo igūdžius, bet suvokimą, kaip architektūra gali prisidèti prie harmoninès socialinès elgsenos stereotipų aktualizavimo, prie psichologinių nuostatų, skatinančių siekti socialinio solidarumo, ugdymo.

3. Todèl svarbus kompozicinių priemonių, galinčių užtikrinti harmoningos socialinès sąveikos nuostatų aktualizavimą, socialinio solidarumo nuostatų itvirtinimą, pažinimas, o tam ypač svarbu šiuo aspektu ịvertinti mūsų šalies ịvairių laikotarpių įžy- mių architektų kūrybą; vienu iš tokių architektų yra V. Landsbergis-Žemkalnis, kuriam architekto atsakomybè visuomenei buvo itin svarbi.

4. Architekto V. Landsbergio-Žemkalnio darbų analizè parodè, kad jo kūrybai būdingas organiškojo kompozicinio tipo vyravimas, o kartu - socialinio solidarumo programavimą užtikrinančių architektūrinių kompoziciniu priemonių dominavimas.

5. Ypač šiomis programuojančiomis savybemis pasižymi V. Landsbergio-Žemkalnio pastatai, esantys pačioje miesto širdyje - Naujamiestyje. Tai pasireiškia tuo, kad šie pastatai yra daugiau miestietiško tipo, aktyviai kompoziciškai „bendradarbiauja“ su gretimais pastatais, su visa gatvès erdve.

6. Tolstant nuo centro, pastatuose gausejja vertikalių elementų, daugiau skiriasi atskirų pastato dalių aukštis, siluetas darosi aktyvesnis, dinamiškesnis. Tipologiškai tai būdingi priemiesčių ar užmiesčių pastatų, kurie pretenduoja ị lokalinio kompozicinio centro vaidmenį, bruožai.

7. Apskritai V. Landsbergio-Žemkalnio kūryba liudija apie jo sugebejjimą perprasti urbanistinę situaciją ir joje deramai parinkti statinio kompozicinius parametrus, ypač tankiai užstatytoje aplinkoje, kur vaizdinis solidarumo pateikimas yra itin aktualus.

\section{Literatūra}

Bieliauskaitè, J. 2009. Solidarumo vaidmuo socialinèje teisinèje valstybeje, Socialiniu mokslu studijos I(I):79-94.

Grybauskaitè, D. Lietuvos Respublikos Prezidente [interaktyvus] [žūrèta 2010-07-29]. Prieiga per internetą: $<\mathrm{http}: / /$ www.president.lt/lt/prezidento_institucija/prezidente_dalia_grybauskaite/prioritetai.html>.

Guogis, A. 2006. Kai kurie socialinio solidarumo praradimo aspektai Vakaruose ir Lietuvoje, Socialinis darbas 5(1): 9-13.

Kančienė, J. 1991a. Prekybos, pramonès ir amatų rūmai K. Donelaičio g. 8, iš Kauno architektūra. Vilnius: Mokslas, 86-88.

Kančienè, J. 1991b. „Pienocentro“ rūmai Laisvès al. 55, iš Kauno architektūra. Vilnius: Mokslas, 143-144.

Kančienè, J. 1991c. Kūno kultūros rūmai Sporto g. 6, iš Kauno architektūra. Vilnius: Mokslas, 285-287.

Kančienè, J. 1991d. Tyrimų laboratorija Radvilenų pl. 19, iš Kauno architektūra. Vilnius: Mokslas, 287-289.

Kančienè, J. 1991e. Apskrities savivaldybė Vytauto pr. 91, iš Kauno architektūra. Vilnius: Mokslas, 345-346.

Kančienè, J. 1993. Gyvenimas - tai küryba. Architektas Vytautas Landsbergis-Žemkalnis. Vilnius: Mokslo ir enciklopedijų leidykla, 7-55.

Landsbergis-Žemkalnis, V. 2009. Iš atminties ekrano: rašyta ir pasakota. Vilnius: Versus aureus. $520 \mathrm{p}$.

Petrušonis, V. 2004a. The place of architecture in the realms of imagination and responsibility, iš Американские 
исследования: ежегодник, 2003, часть II. Минск: Пропилеи, 278-286.

Petrušonis, V. 2004b. Introdukuotieji kultūriniai klodai Kauno architektūroje, Urbanistika ir architektūra 18(3, priedas): $57-62$.

Petrušonis, V. 2005a. Cultural space as chaos redefining order. Sacrum in cultural space. Stockholm: Institute for Art and Culture, 70-76.

Petrušonis, V. 2005b. Simetrinès kompozicijos hipersemantinis aspektas, iš Tekstai ir kontekstai: kalbos judesys. Kaunas: VU leidykla, 551-568 (rusų k.).

Petrušonis, V. 2007. Broken silhouette of a building: mystique and ethics, Urbanistika ir architektūra 31(1): 39-42.

Кильен, Ж. 1983. Культура [Bildung] и разум у В. фон Гумбольдта, в кн.: Разум и культура. Труды международного франко-советского коллоквиума. Лилль, 26-29 апреля 1978 года. Москва: Издательство МГУ, 156-169.

Кириченко, Е. 1979. Пространственно-временные характеристики в русской архитектуре середины и второй половины XIX в., в кн.: Типология русского реализма второй половины ХІХ века. Москва: Наука, 286-351.

Любищев, А. А. 1977. Понятия системности и организменности, Труды по знаковым системам IX: 134-141. Тарту.

Петрушонис, В. 2006. Средства оперирования контекстом в процессе культурной идентификации, в кн.: Американские исследования: ежегодник, 2004-2005. Минск: Пропилеи, 394-404.

Раш, М. 1991. Менеджмент: Библейский nyть. Bielefield: Logos. 215 p.

Фромм, Э. 1992. Душа человека. Москва: Республика. 430 с.

Швейцер, А. 1988. Мировоззрение индийских мыслителей. Мистика и этика, в кн.: Восток - Запад. Исследования. Переводь. Публикаиии. Москва: Наука, 209-233.

\section{MOTIVES OF SOCIAL SOLIDARITY \\ IN THE OEUVRE OF THE ARCHITECT \\ VYTAUTAS LANDSBERGIS-ŽEMKALNIS}

\section{Petrušonis}

Abstract. In contemporary society marginalization, alienation of social groups is increasing. Among other things, it is related to changes in the phenomenon of social solidarity, which are influenced by the processes of individualization, diversification, globalization, segmentation. Architectural works of modern architects, that together with customers represent the attitudes of nowadays, often reflect the desire to dominate. While educating young architects it is important to provide them not only with technical and artistic skills, but also to make them understand how architecture can take part in the the actualization of harmonic social behaviour stereotypes, the psychological attitude to encourage the pursuit of social solidarity. It is therefore important to learn how architectural composition can ensure a harmonious social interaction. The related adequate experience is worth studying. It is particularly important to evaluate the works of different periods of our country's famous architects. V. Landsbergis-Žemkalnis could be distinguished as one of such architects to whom responsibility to society was particularly significant. Analysis revealed that V. Landsbergis-Žemkalnis' works are characterized by predominance of an organic compositional type what means that the programming of social solidarity attitudes by architectural compositional measures is ensured. In particular, these properties are characteristic of V. Landsbergis-Žemkalnis buildings realized in the heart of Kaunas city. These buildings are better harmonizing with adjacent buildings and the whole street space. Moving away from the center, in the buildings erected by V. Landsbergis-Žemkalnis design, the number of vertical elements increases, separate parts of a building have a more distinct height, the silhouette becomes more active, more dynamic. Typologically such a building could be assigned to the hierachical compositional type. In contrast to "buildings of the street", "of the city", these buildings represent "suburban" buildings, what claims to be a local compositional center. Altogether V. Landsbergis-Žemkalnis` works illiustrate his ability to "read" the situation in an urban context and use properly selected compositional building parameters, especially properly chosen measures operating in a dense group of existing buildings where the solidarity phenomenon is of great importance.

Keywords: oeuvre of V. Landsbergis-Žemkalnis' architectural composition, organic compositional type, hierarchical compositional type, impact of architectural forms on the consciuosness of the human, social solidarity, ethics.

\section{VYTAUTAS PETRUŠONIS}

Dr, Assoc Prof, Dept of Fundamentals and Theory of Architecture, Vilnius Gediminas Technical University (VGTU),

Pylimo g. 26/Traku g. 1, 01132 Vilnius, Lithuania.

E-mail:v.petrusonis@tkti.lt.

Doctor of the Humanities (architecture), VGTU, 2005. Research interests: respectation of locus' cultural identity, structural and typological features of architectural objects, metacritical analysis of architectural activity. 